\title{
Christian Ethics in a Corrupt Society: A Challenge to Christians in Nigeria
}

\author{
Friday Ifeanyi Ogbuehi \\ http://dx.doi./org/10.4314/ujah.v18i2.19
}

\begin{abstract}
Christian ethics revolves around morality that concentrates on whether an action is morally good or bad. It implies that Christian ethics which is a branch of religious ethics ensures that people's actions are in tandem with the acceptable moral standard, thereby contributing a lot in human moral development. It becomes worrisome that despite Christian ethics, corruption is perpetrated freely in Nigeria without those concerned having requisite moral Compunction to abstain from corrupt acts. This ugly situation diminishes the role of Christian ethics in human moral development. Therefore it has become necessary to examine the factors that militate against Christian ethics in Nigeria which has made it possible for people, particularly politicians to engage in all sorts of corrupt acts. The work made use of phenomenological approach. It was descriptive and analytical. The work used primary and secondary sources. The primary source includes observation while secondary sources include books, journals, internet materials, encyclopedia and so on. Despite the fact that Nigeria is predominantly Christians, Nigeria is classified as one of the most corrupt countries in the world. There is no doubt that most of the Christians do not apply Christian ethics in their workplace due to Colonialism, Secularization, Materialism, change of moral values, irreligious attitude, Family background, Western influence, Imported religion and so on.
\end{abstract}

Keywords: Christian, Ethics and Corruption 


\section{Introduction}

Christian ethics is concerned with the morality of human conduct. It is interested in what ought to be done in a given situation. Christian ethics Judges every action of human beings with the motive of ascertaining whether the action is good or bad. Christian ethics is indispensable, particularly in Nigeria where almost the majority of citizens are Christians. "According to the pew research center, Nigeria has the largest Christian population of any country in Africa, with more than 85 million persons in Nigeria belonging to the church with various denominations". (Wikipedia, the free encyclopedia).It has been the expectation of people that Christians should have imbibed Christian ethics that would have made Nigeria, an upright Country.

The former president of Nigeria, Olusegun Obasanjo when he was signing Anti-corruption bill into law in the National Assembly of the Federal Republic of Nigeria on Tuesday, June13,2000 made it clear that Christian ethics and morality are the norms of decent society and the bedrocks of building wholesome, efficient, just and prosperous Nigeria. (http://www.eurojournals.com). But, it is regrettable that Christian ethics has failed to accomplish the expectation of people as an instrument of moral upbringing of Nigerians. Unfortunately, many people claim to be Christians in Nigeria, yet there is nothing to show in terms of moral integrity. The high rate of corruption in Nigeria is an evidence that Christian ethics has done little or nothing in controlling some political and religious leaders' unquenchable thirst to siphon public funds meant for the welfare of poor masses. Therefore, it is pertinent to examine the factors that are responsible for the inability of Christian ethics to checkmate corruption in Nigeria. 
The work made use of phenomenological approach. It was descriptive and analytical. The Sources used were primary and secondary sources. It used primary source such as observation and secondary sources which include books, journals, internet materials, dictionaries and encyclopedias. Discovery has shown that in Christianity the relationship between Christian ethics and Christianity is not in contention. But, Christians in Nigeria find it difficult in applying Christian ethics in their private and public domains due to some factors which include, colonialism, Secularization, Materialism, Change of moral values, irreligious attitude, Western cultural influence, family background and imported religion. This ugly scenario has enabled corruption to thrive in Nigeria.

\section{Christianity and Ethics}

In this section, efforts will be made to relate ethics to Christian faith. Christian ethics is distinct from other disciplines of ethics such as Islamic ethics, African Traditional ethics, and ethics of other world religions. Christian ethics has been understood as a discipline of moral Theology that avails itself of revelation and supernatural forces in the study of human conduct (Iwe 2003:1819).Therefore, Christian ethics deals with discourse about Jesus Christ and how the knowledge acquired through theological reflection about Jesus Christ can be brought to bare in the study of human conduct. Ferguson and Wright (1988:445) insisted that Christian ethics as a branch of moral theology (theologia moralis) is concerned with the practical questions of Christian morality. For instance, is it good for a Christian to commit abortion? Is it good for a Christian to use contraceptives? Is it good for a Christian to give and receive bribe? 
As far as Christian ethics is concerned, the bible is indispensable as a resource material that enables a Christian to judge whether his action is compatible or incompatible with the bible. In collaboration with this view, Nwaike (2000:91) opines that "However, Christian Ethics could be found in the life and teachings of the founder as well as in those of his apostles.... This good life, Christians believe, is only attainable by behaving in accordance with God's precepts". There is no gainsaying that any act that is not in agreement with the stipulations of the Bible is regarded as bad while act that is acceptable according to the biblical standard is considered good.

It must be noted that Christian ethics cuts across personal piety to the application of faith to one's practical life. Haselbarth (1976:1) observes that Christian ethics sees to the reflection of the Bible with the aim of cultivating a Christian life-style that showcases in both personal and social relations. Christian ethics is not a theoretical venture rather it is part and parcel of Christian faith. The application of Christian ethics in socio-political and economic sphere of life becomes difficult when a Christian depends on human strength and philosophies. Haselbarth (1976:2) asserts that if a Christian wants to practice Christian ethics, he must be guided by revelation and Holy Spirit. In Christian ethics, the Holy Spirit is indispensable, considering the vital role Holy Spirit plays in bringing enlightenment of the Scriptures as well as helping a Christian to overcome persistent temptations that stare him at his face.

Christian ethics is not merely a study of human conduct alone, it encompasses the inculcation of right moral principles among Christians, particularly those who believe and share the moral 
principles. Alexander (2007:57-58) avers that "Christian Ethics treats every man as accountable for his thoughts and actions, and therefore, as capable of choosing the good as received in Christ". The eschatological dimension of Christian ethics imparts in Christians the attitude of Christian stewardship. Christian stewardship makes accountability its watchword. Chukwuma (2008) eloquently affirms that

A Christian-politician would normally face two opposing choices, either to do his duties for which he is elected and receive the blessing from God and the praises of his people without enriching himself or herself, or grasp all the money that is meant for social development and enrich himself, and face the wrath of God and the curses of the people and so earn a bad name (p.215).

By so doing, Christian ethics inculcates fear of God among Christian politicians to avoid bribery and corruption and work toward the growth and development of Nigeria. But, it becomes a paradox when Christian politicians who suppose to be guided by Christian ethics are not influenced by the tenets of Christian ethics.

For some people, love is the summum bonum of Christian ethics. Okai (2008:110) quips that Christian ethics as a branch of moral philosophy is rooted in love. For many people love is the foundation of Christian ethics. In Christianity, love is central in judging Christian actions. Christians are directed to love their neighbours as themselves. Consequently, egocentricism (love of self) is a misnomer in Christian ethics. Christian ethics is interested in discouraging self-centredness and encouraging selfless attitude that transcends 'self' and shows concern for the welfare of one's 
neighbour. Christian ethics encourages patriotism which raises love of one's country above love of 'self'. Christian ethics motivates Christian political leaders to shun acts that are capable of being detrimental to the welfare of their country and neighbours (citizens). There is no doubt that if Christian political leaders abide by the ethical principles of love of Nation and neighbours, it will be difficult for political leaders to plunder public funds for their selfish aggrandizement.

It is observed that there is no universal moral standard among the Christian denominations in Nigeria. In Christian ethics, what is good for a denomination may be bad in other denominations. This accounts for the ethical relativism that is prevalent among Christian denominations. Nwaike (2000:92) avers that "But the differences in practice as seen in the different Christian sects are simply casuistical differences (ie. differences in the list of things acceptable by each group (sect) as good, eg. birth control). There are ethical conflicts between the protestant churches and the Orthodox Church (Roman Catholic and Anglo Catholic churches). The visible ethical Conflicts that exist between the reformed churches and the Orthodox Church include closing of hair, bringing corpse into the church, mourning for the dead, dressing code (putting on trousers and wearing of mini skirts to the church), receiving medical treatment, eating of meat or vegetables and so on. All these conflicting ethical principles are yet to be reconciled among the denominations in Nigeria.

As a result of the above reasons, it has led some people to think that universal moral standard among the denominations is untenable. The varying ethical principles stem from the fact that there are different denominations with different doctrines. Gbenda 
(2006:76) opines that it is difficult to have a homogenous Christian ethics owing to the multiplicity of churches which include mission churches, Independent African Churches and Pentecostal churches that share varying doctrines and ethical values. The divergence in Christian ethical orientation among denominations has been a source of confusion to Christians in making moral choices. Apart from doctrinal controversies that surround Christian ethics, there is another problem of contextualization of Christian ethics to reflect African beliefs, experiences and aspirations.

Christian ethics is played down among Christians who believe that Christian ethics did not originate from the bible, rather it was informed by human wisdom and experiences. Nowell-Smith (1999:404) claims that even if Christian ethics was derived from the bible, the bible is just an "amalgam of profound wisdom and gross superstition". It has been discovered that ethical principles in the first century may not suit the complex ethical decision making in the twenty first century.

Christian ethics is founded on a precarious foundation of the bible due to the controversies that have confronted the authenticity of the bible. Madu (1996:108) asserts that it may be impossible to know what is morally good or bad from the bible since there are discrepancies, incongruities, inconsistencies and paradoxes that are replete in the bible. In collaboration with this view Obeng (1997) opines that

the biblical texts have been handed down through the centuries. They have been subjected to distortion and human error. A weary scribe might make mistakes unintentionally. The texts can also be altered deliberately 
by someone anxious to make them more relevant or more accurate, by his estimation. The texts may have been damaged accidentally by age or misuse or accident (p.9)

It becomes difficult for a Christian to rely on the bible as a source of Christian ethics due to the obvious mistakes that are visible in the bible.

There are some people who hold that morality which is believed to be an offshoot of Christianity has nothing to do with God and the bible. Idowu (1962:144) opines that morality is a product of the society which is aimed at preserving the society, hence morality is a social phenomenon. The society created the "ought" and conscience which were implanted in man during his early stage of development. It is the society that determines what is good and what is bad through their traditions, customs and laws. Idowu further avers that morality developed out of common sense. In a bid for man to adjust to his environment, experience taught him what to do and what should be avoided. It was the accumulation of this experience for a long time that instilled into human beings the sense of right and wrong.

\section{The concept of Corruption.}

It should be stated that corruption is a broad term that covers every aspect of human existence. Eze (2002:3) opines that corruption constitutes social ills that are going on in Nigeria. Corruption covers social ills which include bribery, stealing, telling lies, murder, prostitution, indecent dressing, examination malpractice, Abortion, indiscriminate dumping of refuse, kidnapping, human trafficking, diversion of public funds and so on. Ikubaje (2006:11) quoted Nye as saying that corruption occurs when a person 
deviates from his formal duties as a result of selfish interests. A public servant commits corrupt act when he disregards the rules that govern his duty in order to fulfill his selfish ambition. In collaboration with this view, Anyacho (2013) described how a Civil Servant can deviate from his formal duties for privateregarding which he avers that

In Nigerian context, corruption includes such behaviours as diversion of public fund to private purses, not being obliged to discharge an obligation, employment of unqualified persons in jobs they are not qualified to do because of the advantage the employers would get from such employee. Looting public treasury in order to enrich oneself, changing or doctoring election results to favour unpopular contestant (p.131)

All these corrupt acts are visible in Nigeria where tribal and ethnic considerations hold sway in the discharge of one's duty.

There are other ways corruption is perpetrated in Nigeria. Kunhiyop (2008:165) asserts that corruption can take the form of outright theft, match - fixing, examination fraud, kick backs, illegal awarding of contracts, rigging of elections, purchase and sale of votes and falsification of election results. No country can claim that it is corrupt free when features of corruption are found in that country. Coker (2006:92) avers that corruption occurs when a political leader or civil servant abuses or misuses his power for private benefits which range from money, protection, special treatment, commendation, promotion to favour of women and men. Therefore, corruption does not consist of monetary involvement only. Corruption can take place either in cash or kind. 
There is no doubt that corruption disrupts human relationships. Ekwunife (2011:95) quips that "when man convincingly and willingly posits overt and covert actions calculated to soil or disrupt human relationships or relationships with animate or inanimate objects on the one hand, in man's horizontal plane and relationships with trans-human Beings in man's vertical plan". Corruption is not limited to human society alone. It can also occur when a person does wrong against the supreme being and the inanimate beings. Corruption is committing evil against God and humanity, it should be avoided by all. To say that corruption is retrogressive and anti-social is to state the obvious. It has been discovered that a corrupt person is an immoral person. Omoregbe (1993:x) asserts that "By an immoral society we mean a society permeated with corruption, dishonesty, fraud, selfishness, embezzlement of public funds and other immoral acts". A corrupt society is an immoral society that has lost sense of morality. There is no doubt that Nigeria is a corrupt society where immoral acts are carried out with impunity.

\section{Theoretical Framework}

The theory of secularization was used in the work to showcase how secularization has affected Christian ethics by depriving it the opportunity of influencing public servants positively in the discharge of their duties. Anyacho (2011:389) asserts that secularization was derived from the Latin word saeculum which literally means "time", age or generation. The latin word saeculum connotes world or women affairs in time. It should be stated that the term secular was derived from the same Latin root word to describe what happens here and now which does not has any relationship with the religious sphere. Anyacho (2011:390) avers that the term secularization was first used in Europe in 1648 
during the peace of Westphalia to describe the relinquishing of territories that were formally under ecclesiastical control to the political authorities. Secularization means separation of secular from spiritual sphere. Inyama (1997:133) opines that "secularity then means that political order of the state shall be responsible for the temporal welfare of the citizens while the religious matters should be left to the religious order". Secularization prevents religious principles from influencing political polices and decisions. Ituma (2008:36) quips that in secularization, there are dumping of religious values which showcases in the decline of piety and respect for the sacred. The theory of secularization was used in the work, considering the fact that Nigeria is a secular country.

\section{Christian Ethics and corruption in Nigeria}

Christianity as a religion preceded the amalgamation of Nigeria in 1914 by Lord Lugard. The advent of Christianity in Nigeria marked the beginning of Christian ethics in Nigeria. Gbenda (2006:12) opines that Christianity came to Nigeria as far back as $15^{\text {th }}$ century by Portuguese traders and missionaries. The points of contacts were Benin and Warri. But, it failed as a result of slave trade that ravaged Africa then, particularly Nigeria. Christianity made an inroad in Nigeria for the second time in the $19^{\text {th }}$ century. It was in the $19^{\text {th }}$ century that Christianity succeeded in Nigeria and imparted Christian ethics in the minds of its adherents.

Odey (1999:40) asserts that Christian ethics lost its grip on the citizens of Nigeria when government took over the private schools, particularly the mission schools. The government of the East central state of Nigeria under the leadership of Ukpabi Asika issued an edict that transferred the ownership of private schools 
from private agencies to the state on May 26, 1970. It was at that time that mission schools were taken over by the state government. Ilori (2002:18) opines that since the takeover of schools from the missions, character formation in the secular schools has been relegated to the background. It is pathetic that most of the products of secular schools today are those who champion corruption in all levels of government, unlike the products of mission schools who are still reckoned with in terms of discipline in whatever responsibility entrusted to their charge.

It is perplexing to observe that the church that supposes to give moral direction for the political leaders and the led to follow has lost influence on the society. Anyacho (2011:389) asserts that Christian values that were cherished by the people have been thrown overboard in the twenty first century. Most of the Christians no longer allow Christian values to guide their actions in their homes and workplace. It is unfortunate that despite the religious boom, especially Christian activities such as crusades, bible study, prayer meetings, Christian workshops and seminars that are prevalent in Nigeria yet corruption is soaring high on daily basis. Odey (1999:78) opines that catholic Bishops of Nigeria admitted the reality of corruption in Nigeria when they decried that Nigeria was listed the most corrupt Nation by transparency international on two consecutive years. Kagarko (2008:136) attributed the high rate of corruption in Nigeria to church's involvement in corruption.

It is regrettable that the church which Nyerere (1997:109) avers should fight for the society in eradicating exploitation and sharing of National wealth has become part and parcel of corruption that is going on in the system. The former Governor of Rivers State and 
the Director-General, Buhari Presidential campaign organization, Rotimi Amaechi during the all progressive people's congress (APC) governorship campaign rally at Emohua Local Government Area, Rivers State, accused some church leaders of collecting bribes of N7 billion from the peoples' Democratic party (PDP) to campaign against Muhammadu Buhari who was the presidential candidate of All Progressives Congress, APC. He further revealed that the church leaders concerned have printed and distributed leaflets accusing Muhammadu Buhari of Islamizing Nigeria if elected the president of Nigeria. A pastor who resides in Borno, Kallamu Musa-Dikwa after the allegation admitted that the president gave the pastors N7bn (Ajomole 2015:np). It is worrisome to note that pastors who should have fought bribery and corruption are now benefiting from moral decay that persists in Nigeria.

\section{Factors that Militate against Christian Ethics in Nigeria}

1. Colonialism - The brutal and harsh experience of colonialism in Nigeria cannot be forgotten in a hurry. In the colonial era, Nigeria passed through oppression and exploitation. The Nationalists hate Christianity due to the claim that Christianity collaborated with colonial rule that committed all sorts of injustices in Nigeria. In collaboration with this view, Onwurah (1999:149) described Christianity as "white mans' cult, a king of imperialistic witchcraft, employed to fetter the souls of people for the sinister purpose of colonial exploitation". Consequently, most citizens of Nigeria disregard Christian ethics on the grounds that the early Christian missionaries aided and abated colonial oppression and exploitation. 
2. Secularization - It is widely held that Nigeria is a secular country where religion is separated from politics. Onah (2014:14) quips that secularism was debated in Assembly in 1978 as regards to sharia court of appeal. Section 10 of 1979 and 1999 constitution says that "The Government of Federation or of a state shall not adopt any religion as state religion". Therefore, there is no platform for the influence of Christian ethics on the political leaders of Nigeria.

3. Materialism - The quest for acquisition of wealth among Nigerians has resulted to some people abandoning Christian ethics. Onuoha (2011:366) opines that materialism occurs when people are preoccupied with worldly materials and lose sight of spiritual matters. The corrupt enjoy their ill-gotten wealth without considering the eschatological implication of their actions. Therefore, many people acquire wealth through foul means at the expense of Christian ethics.

4. Change of moral values-Many people have accused Christians of changing traditional moral values that held the African society together without providing suitable replacement. It is based on this that Idowu (1962:209) asserts that the church contributed to the detrimental changes in moral values. At the inception of Christianity, the early Christian converts were taught that African gods had no power and should not be feared. The new Christian orientation against the African gods resulted to lack of fear of gods by Africans, people can now steal without any moral compunction those goods displayed for sale at cross roads and by the road side that used to be safe. The church has not relented in condemning traditional oath-taking used by Africans to detect culprits of one offence or the other as well as an instrument of 
ascertaining the truth as fetish. Onyeidu (2004: 42-43) opines that Christians are not serious with the bible as an instrument of detective. Many Christians swear falsely with the bible, and the resultant effects are perjury in age declaration, affidavit for lost credentials, death certificates and change of ownership of property. The African people are at the cross roads in terms of making moral decisions due to Christianity has cut the moral apron string that held the people for generations and moral decadence has become the order of the day.

5. Irreligious Attitude - Many people who are addressed by Christian names still involve in one crime or the other. There are a lot of people who attend church services yet they hardly allow Christian principles and ethical demands to guide their moral decision making. Many church goers are interested in miracles more than salvation. Most of the pastors in Nigeria have changed from preachers of the gospel to prosperity preachers without considering its implication on the wellbeing of the society. There are cases where some Christians involve in ritual killing, stealing, distribution of counterfeit drugs and goods and embezzlement of public funds in a bid to become prosperous.

6. Western Influence - Western culture has tremendously influenced Christian ethics in Nigeria. Elford (1995:357) attributed the influence of secular morality on Christian ethics to the secular enlightenment of the eighteenth century. The enlightenment and the renaissance led to the revision of Christian ethical principles to suit the changing situation occasioned by the development in science and technology in Europe. Kunhiyop (2008:34-35) quips that Jeremy Bentham propounded utilitarianism that states that an action is right as long as it can produce the greatest happiness for 
the greater number of people while Joseph Fletcher is the proponent of situational ethics that advocates that the rightness and wrongness of an act depends on the situation. In some western countries unethical practices such as same sex marriage, abortion, homosexualism, lesbianism, prostitution, pornography, divorce, suicide, drug addiction are not only legalized but have also received approval. Unfortunately, some of these countries that have legalized these abominable acts were the same countries that regarded Africa as savages which motivated them to send Missionaries who evangelized Africa, especially Nigeria.

7. Imported Religion - The Traditionalists often refer to Christianity as an imported religion. Others prefer to call it a white man's religion. Consequently, they also treat Christian ethics as imported ethics and white man's ethics that is not relevant in Nigeria. Therefore, it becomes, difficult for Christian ethics to have any influence on their lives.

8. Family Background - The sociologists say that family is the smallest unit of the society. It is also the microcosm of the society. Ebenebe (1995:153) asserts that the social ills that are in Nigeria are traceable to various families that make up Nigeria. The fact remains that if families are morally sound, Nigeria will also be morally upright. Therefore, families in Nigeria should endeavour to inculcate good moral principles in the minds of their children at a tender age to enable them live upright lives and avoid all sorts of corrupt acts in future.

\section{Recommendations}

1. Christians in Nigeria should allow Christian ethics to guide them in everything they do. 
2. Christians should shun giving and receiving bribes.

3. Christian religious leaders should organize seminars, workshops and conferences where both the political leaders and the led will be taught the consequences of engaging in corrupt acts.

4. Christian religious leaders of various denominations in Nigeria should have dialogue with all the denominations with the aim of resolving Christian ethical conflicts among them.

5. Christian religious leaders should emphasize more on salvation and avoid emphasis on prosperity preaching.

6. The political leaders should hand over mission schools to the original owners in order to restore discipline in the school system in Nigeria.

7. The political leaders should inculcate patriotism in the minds of the youths who are future leaders of Nigeria through civic education.

8. The political leaders should not allow secularization to deprive them of the opportunity of taking heed of wise counsel by Christian religious leaders which will help them to formulate polices that will usher in good governance in Nigeria.

\section{Conclusion}

In conclusion Christian ethics stresses on the importance of stewardship and accountability which are antidotes of fighting bribery and corruption in Nigeria. But, many Christians do not apply Christian ethics in the discharge of their public responsibilities due to colonialism, secularization, materialism, change of moral values, irreligious attitude, western cultural influence, family background and so on. The relegation of Christian ethics to the background in both private and public sectors has resulted to the prevalence of corruption in Nigeria. But, 
if the citizens of Nigeria can imbibe Christian ethics and apply it to their daily lives, corruption will be a thing of the past in Nigeria. It will also restore the vital position Christian ethics occupies as an instrument of human moral development.

Friday Ifeanyi Ogbuehi

Trinity Theological College

Umuahia

ogbuehifriday@yahoo.com

\section{References}

Agha, A. U. (2003). Religious Ethics in a Permissive society. Enugu: SAPS.

Ajomole. H. (2015). Top 12 Corruption cases in Nigeria. https://www.naij.com. Retrieved $1^{\text {st }}$ April, 2016.

Alexander, A. B. (2007). Christianity and Ethics. Aba: inestimable life publications

Anyacho, E. O. (2011). Influence of secularization On Christianity in Nigeria. Aspects of Religious studies and philosophy (Ed) Okereke C.C and Nwoko M.N. Owerri Skillmark media limited.

Anyacho, E.O. (2013). Religion in society. Anambra: C. P. Globe

Chukwuma, J.N. (2008). Christian Religion And the task of Nation Building . Nsukka Journal of Religious studies (Ed) Ugwu.

C. O. T. volume 2 number 1.Nsukka: Department of Religion.

Coker, M. A. (2006). Corruption and direct Foreign investments in Nigeria. Sophia An African Journal of philosophy (Ed) Uduigwomen A.F. Volume 9 Number 1. Calabar: Department of philosophy. 
Ebenebe, .R. (1995). Changing Children's Behaviour. Family stress management (Ed) Ezeilo B.N. Enugu: Abic Publishers

Ekwunife, A.N.O (2011). What will be, will be Why pray. Lagos: priceless prints

Elford, R.J. (1995). Questions people Ask why bother about religion?. The Expository Times (Ed) Rodd C.S volume 106 number 12. Edinburgh: T and T Clark Limited.

Eze, N. (2002). The causes of corruption In Nigeria and the way forward. corruption in Nigeria: critical Perspectives A book of Readings (Ed) Ugwu C.O.T. Nsukka: chuka Educational publishers.

Ferguson, S. B and Wright. D. F. (1988). New Dictionary of Theology. England: Inter-varsity press

Gbenda, J. S. (2006). African Religion and Christianity in a changing world a comparative Approach. Nsukka :Chuka Educational Publishers.

Haselbarth, H. (1976). Christian Ethics In the African context. Ibadan: Daystar press.

Idowu, E.B. (1962). Olodumare God in Yoruba Belief. London:longman Group Limited.

Ikubaje, J. (2006). Corruption and Anti-Corruption:Revenue Transparency in Nigeria's oil Sector. Lagos: Joe - Tolalu and associates.

Ilori, J. (2002). Philosophy of Christian Education An African perspective. Bukuru: Africa Christian Textbooks

Inyama, E. O. (1997). Religion and politics in Nigeria. Nigerian politics (Ed) Ndoh C.A and Emezi C.E .Owerri: CRC. Publications Limited.

Ituma, E.A (2008). The significance of ChristianYouth Development in Eradicating Corruption In Nigeria: Luke 
2:41-52. Nsukka Journal of Religious Studies (Ed) Ugwu C.O.T Volume 2 Number 1. Nsukka : Department of Religion.

Iwe, N. S. S. (2003). The Inseparable Social Trinity: Religion morality and Law An inaugural lecture delivered at the university of Calabar, Cross Rivers state in $14^{\text {th }}$ August, 2003. Calabar Seasprint Company.

Iwe, N.S.S. (2011). Religion, morality and Ethics. Readings in the scientific Study of Religion (Ed) Okon. E. E. Calabar: University of Calabar press.

Kagarko, G. (2008). Nigeria is a secular Society but her citizens are Religious. Nigerian Journal of Humanities and Social sciences (Ed) Ugwu C.O.T volume 2. Nsukka: centre for Academic Research.

Kunhiyop, S. W. (2008). African Christian Ethics. Nairobi: word Alive publishers.

Madu. J. E. (1996). Fundamentals of Religious Studies. Calabar: Franedoh publishers.

Nowell-Smith, P. (1999). Morality: Religious and secular. Philosophy of Religion:The Big Questions (Ed) stump E and Murray M.J. USA: Blackwell publishing Limited.

Nwaike, E. C (2000). Ethics in A permissive Society. Owerri: Springfield publishers.

Nyerere, .J. (1997). The Church's Role in Society. A Reader in African Christian Theology $(\mathrm{Ed})$ parratt.J. London: SPCK.

Obeng, E.A. (1997). The use of Biblical critical Methods in rooting the scriptures in Africa. The Bible in African Christianity (Ed) Kinoti H.W and Waliggo J.M. Nairobi: Acton publishers.

Odey, J.O. (1999). Christians, politics and the Nigerian Dilemma. Enugu. SNAAP Press Limited. 
Okai, M. O. (2008). Religion and social conflict management. Port Harcourt: Cal integrated Resources limited

Okwueze, M. I (2003). Ethics, Religion and Society. Nsukka: Prize publishers.

Omoregbe, J. (1993). Ethics A systematic and Historical study .Lagos: Joja Educational Research and publishers limited.

Onyeidu, S.O. (2004). Christianity and Society. Enugu: EasyQuality publishers.

Onwurah, E. (1999) .The Quest, Means and Relevance of African Christian Theology. Issues in Theology, Mission, Church and Society (Ed) Uka. E.M. Calabar: University of Calabar press.

Onah, J. N. (2014). Religious Fanaticism in Nigeria and its implication to National Development. A seminar paper presented to the Department of Religion and Cultural studies, University of Nigeria Nsukka.

Onuoha, E.O. (2011). Spirituality or materialism: The dilemma of contemporary church in Nigeria. Aspects of Religious studies and Philosophy (Ed) Okereke C.C and Nwoko.M. N. Owerri: Skillmark Media limited.

Oyawale. O. (2009). Church workers' Handbook On leadership and Human Relations. Lagos: Foclem Communications.

Uka, E. M. (1999). Romans: A Theology of the Gospel According to Paul. Issues in Theology, mission, church and society (Ed) Uka. E. M. Calabar: University of Calabar Press.

Uka. E.M. (1999). The Church and Nation Building: The challenges of the $21^{\text {st }}$ century. Issues in Theology, mission, church and society (Ed) Uka E. M. Calabar: University of Calabar press.

Wikipedia, the free encyclopedia. https://en.wikipedia.org/. Retrieved $1^{\text {st }}$ April, 2016. 